\title{
Comparative study of Tephrosia purpurea (Linn) leaves and Lovastatin on cholesterol level of hyperlipidemic wistar rats.
}

\author{
Sayyad Mustak ${ }^{1,2,3}$ \\ ${ }^{I}$ Department of Medicine \& Community Health, Faculty of Medicine and Health Sciences, University Putra \\ Malaysia, Serdang, Malaysia. \\ ${ }^{2}$ Department of Pharmacology, Shadan College of Pharmacy, Peerancheru, Hyderabad, India. \\ ${ }^{3}$ Department of Pharmacology, Ganga Pharmacy College, Nizamabad, India.
}

Introduction : Tephrosia purpurea is a polymorphic, much branched, herbaceous perennial herb found throughout the Indian subcontinent, ${ }^{5}$ and according to ayurvedic literature this plant also given the name of "Sarwa wranvishapaka" belonging to the family fabaceae ${ }^{6}$. Flowering and fruiting of plant is mostly observed in months between July-December in Indian condition. Tephrosia purpurea has been established for its phytochemical screening and revealed to contain long chain saturated ketones, glycosides, rotenoids, tephrosin, pongaglabol, semiglabrin, chalcones, sterols, flavanols and flavones. ${ }^{8,11}$ Traditionally plant is being used as tonic, laxative, and diuretic ${ }^{l}$. It is also useful in treating cough \& tightness of the chest, biliary febrile attacks, obstructions of the liver, spleen and kidneys. This plant is specifically recommended as a blood purifier and anthalmintic for children. Roots are given in dyspepsia and chronic diarrhoea. In ayurveda system of medicine, the whole plant has been used to cure tumours, ulcers, leprosy, allergic and inflammatory conditions such as rheumatism, asthma, bronchitis. Its aerial parts and roots are used in bronchial asthma, hepatic ailments, cutaneous toxicities, pain and inflammation ${ }^{8}$.

Key Words: Dexamethasone, Ethanolic extract, Lovastatin, Hyperlipidemia, Tephrosia pupurea.

\section{Study conduct}

\section{Materials \& Methods}

The study was conducted in animal experimentation lab, Shadan College of Pharmacy, Peerancheru, Hyderabad, India.

\section{Plant Material}

The whole plant of Tephrosia purpurea was collected from fields of hyderabad, India. The plant was taxonomically identified and authenticated by Prof. M. Madhavi Principal Scientist \& HOD (All India Coordinated Research Programme on Weed Control), College of Agriculture, Acharya N.G Ranga Agricultural University, Rajendra Nagar, Hyderabad, A.P., India.

The plant leaves were dried under shade and then coarsely powdered with a mechanical grinder. The powder was packed in to soxhlet column and extracted with ethanol $95 \% \mathrm{v} / \mathrm{v}\left(60^{\circ} \mathrm{C}\right)$ and distilled water. The extracts were concentrated using rotary flash evaporator under reduced pressure. The dried extracts were stored in airtight container in refrigerator below $10^{\circ} \mathrm{C}$. The marc left after Ethanolic extraction was dried and then extracted with distilled water, up to $72 \mathrm{hrs}$. After completion of extraction, it was filtered and the solvent was removed by evaporation to dryness on a water bath, green color residue was obtained and it was stored in a dessicator. The solution of ethanolic and aqueous extracts were prepared using distilled water and subjected to preliminary phytochemical screening. Based on results of the preliminary phytochemical screening, ethanolic fraction of extract has been selected for the study.

\section{Animals}

Total thirty wistar rats (both sex) each weighing about 150 - $180 \mathrm{gm}$ were selected and the animals were treated according to the CPCSEA guideline throughout the experiment period. The animals were kept under a conventional light regimen with a dark night at room temperature (about $25-27^{\circ} \mathrm{C}$ ) and humidity. Animals were housed in plastic bottom cages and were allowed free access to standard laboratory feed (Nutrilab brand extruded pelleted mouse feed) and fresh water ad libitum. All the animals have been divided into five groups and placed in separate cages, each consisting of 6 animals. The animals were acclimatized to the laboratory condition for 2 to 3 days, before the onset of experiment. 


\section{Determination of acute toxicity $\left(\mathbf{L D}_{50}\right)$}

The acute toxicity for ethanolic extract of Tephrosia purpurea (Linn) leaves was determined in albino mice, maintained under standard conditions. The animals were fasted overnight prior to the experiment, fixed dose method was adopted as per OECD Guideline No. 420; (Annexure-2d) of CPCSEA. ${ }^{17}$

\section{Experimental treatment}

Animals were divided in to five groups of 6 animals each. Hyperlipidemia was induced in group II, III, IV and $\mathrm{V}$ by subcutaneous injection of Dexamethasone $(10 \mathrm{mg} / \mathrm{kg} / \mathrm{day}$, S.C.) for 8 days. The rats in normal control and hyperlipidemic control groups received normal saline while standard group received Lovastatin (10 $\mathrm{mg} / \mathrm{kg} /$ day, P.O) [Suspended in gum acacia in water] and test group I\&II, received extract by oral route in doses of $400 \mathrm{mg} / \mathrm{kg} /$ day and $800 \mathrm{mg} / \mathrm{kg} /$ day respectively for 14 days of experiment. After the experimental period, the overnight fasted experimental rats were sacrificed by decapitation under light ether anesthesia and blood was collected. Serum from blood was separated and analysed for biochemical parameters (lipid profiles).

\section{Statistical Methods}

Statistical analysis was pwerformed using standard SPSS software, version 19. Oneway-ANOAVA was used as a method to compare the means of different groups.

\section{Preliminary phytochemical screening}

\section{Results}

Preliminary phytochemical screening was carried out for the presence of corbohydrate, proteins, amino acids, steroids, saponins, flavonoids, alkaloids, tannins and glycosides for, ethanolic and aqueous extracts of Tephrosia purpurea (Linn).

Results are shown in Table No.1

\section{Determination of acute toxicity $\left(\mathbf{L D}_{50}\right)$}

The acute toxicity studies of ethanolic extract of Tephrosia purpurea (Linn) was found to be safe and no mortality was found at dose of $2000 \mathrm{mg} / \mathrm{kg}$ b.w. Hence $2000 \mathrm{mg} / \mathrm{kg}$ was $\mathrm{LD}_{50}$ cutoff value for ethanolic extract.

The doses selected for all extracts as per OECD Guideline No. 420 (Annexure 2d) fixed dose method are mentioned below:

Ethanolic extract - $400 \mathrm{mg} / \mathrm{kg}(1 / 5$ of $2000 \mathrm{mg} / \mathrm{kg})$

Ethanolic extract $-800 \mathrm{mg} / \mathrm{kg}$ (double dose of the $1 / 5$ of $2000 \mathrm{mg} / \mathrm{kg}$ )

\section{Serum cholesterol:}

Serum cholesterol levels in dexamethasone induced hyperlipidaemia control group have significantly increased compared to normal rats. The levels were $154.16 \pm 5.01 \mathrm{mg} / \mathrm{dl}$ compared to normal rat group, in which values lie in the range of $76.83 \pm 3.29(\mathrm{mg} / \mathrm{dl})$. However, in the test group treated with $400 \mathrm{mg} / \mathrm{kg}$ and $800 \mathrm{mg} / \mathrm{kg}$, the values were reduced $101 \pm 3.37$ and $99.6 \pm 3.41(\mathrm{mg} / \mathrm{dl})$ respectively. There was a significant reduction $(\mathrm{p}<0.001)$ in total cholesterol values in T.P treated groups. Lovastatin have significantly reduced serum total cholesterol levels to $88.3 \pm 2.78(\mathrm{mg} / \mathrm{dl})$.

\section{Serum triglycerides:}

Serum triglycerides levels reached as high as $95.6 \pm 2.06(\mathrm{mg} / \mathrm{dl})$ in Dexamethsone induced group compared to normal rats in which the values were $57.6 \pm 1.76(\mathrm{mg} / \mathrm{dl})$. In T.P treated groups the values were significantly reduced to $65.6 \pm 3.12$ and $63.8 \pm 3.25(\mathrm{mg} / \mathrm{dl})$ respectively. Lovastatin treated group reduced the value to $68 \pm 2.44(\mathrm{mg} / \mathrm{dl})$.

\section{Serum HDL cholesterol:}

There was significant difference in the serum HDL levels decreased as $22.16 \pm 1.16(\mathrm{mg} / \mathrm{dl})$ in dexamethasone induced group compared to normal group in which the values were $29.6 \pm 2.15(\mathrm{mg} / \mathrm{dl})$. In the T.P treated groups the value were slightly increased to $26.8 \pm 1.6(\mathrm{mg} / \mathrm{dl})$ and $27.6 \pm 166(\mathrm{mg} / \mathrm{dl})$ respectively.

\section{.LDL cholesterol:}

The plasma LDL cholesterol levels in dexamethasone induced group was found to increased significantly than in normal control i.e. $114 \pm 2.3$ Vs $59.3 \pm 2.64$ (mg/dl).In T.P treated groups, the levels were 
reduced to $63.6 \pm 2.75(\mathrm{mg} / \mathrm{dl})$ where as in $800 \mathrm{mg} / \mathrm{kg}$ group value declined to $62.6 \pm 2.74(\mathrm{mg} / \mathrm{dl})$. In lovastatin treated group the value still reduced to $63.3 \pm 2.86(\mathrm{mg} / \mathrm{dl})$.

\section{Body Weight:}

The body weight in the control group increased markedly to $240 \mathrm{~g}$ at the end of the experiment. The normal group weight parameter showed the figure $210 \mathrm{~g}$ at the end of the study. In the extract treated groups the values stood at $230 \mathrm{~g}(800 \mathrm{mg} / \mathrm{kg})$ and $225 \mathrm{~g}(400 \mathrm{mg} / \mathrm{kg})$ respectively. The group treated with the standard drug, lovastatin recorded the weight $220 \mathrm{~g}$ at the end of the experiment.

Table No. 1 Chemical Constituents of Tephrosia purpurea.

\begin{tabular}{|l|l|l|}
\hline $\begin{array}{l}\text { Phytochemical } \\
\text { Constituents }\end{array}$ & Ethanol (95\%) Ext & Aqueous Ext \\
\hline Alkaloids & -ve & -ve \\
\hline Flavanoids & $+\mathrm{ve}$ & $+\mathrm{ve}$ \\
\hline Carbohyd & $+\mathrm{ve}$ & $+\mathrm{ve}$ \\
\hline Saponins & $+\mathrm{ve}$ & $+\mathrm{ve}$ \\
\hline Triterpenes & $-\mathrm{ve}$ & $-\mathrm{ve}$ \\
\hline Sterols & $+\mathrm{ve}$ & $-\mathrm{ve}$ \\
\hline Tannins & $+\mathrm{ve}$ & $+\mathrm{ve}$ \\
\hline Glycosides & $+\mathrm{ve}$ & $-\mathrm{ve}$ \\
\hline
\end{tabular}

Table No. 2 Lipid profile of rats serum treated with tephrosia purpurea and lovastatin:

\begin{tabular}{|c|c|c|c|c|c|}
\hline Parameters & N C & HC & SD & TG- I & TG- II \\
\hline $\begin{array}{c}\text { T.Cholesterol(mg/dl) } \\
\text { Mean } \pm \text { SEM }\end{array}$ & $76.8 \pm 3.29$ & $154.16 \pm 5.01$ & $88.3 \pm 2.78$ & $101 \pm 3.57$ & $99.6 \pm 3.41$ \\
\hline $\begin{array}{c}\text { TriGlycerides(mg/dl) } \\
\text { Mean } \pm \text { SEM }\end{array}$ & $57.3 \pm 1.76$ & $95.3 \pm 2.06$ & $68 \pm 2.44$ & $65.6 \pm 3.12$ & $63.8 \pm 3.25$ \\
\hline $\begin{array}{c}\text { HDL (mg/dl) } \\
\text { Mean } \pm \text { SEM }\end{array}$ & $29.6 \pm 2.15$ & $22.16 \pm 1.16$ & $24.5 \pm 1.82$ & $26.8 \pm 1.6$ & $27.6 \pm 1.66$ \\
\hline $\begin{array}{c}\text { LDL (mg/dl) } \\
\text { Mean } \pm \text { SEM }\end{array}$ & $59.3 \pm 2.64$ & $114.6 \pm 2.37$ & $63.3 \pm 2.86$ & $63.6 \pm 2.75$ & $62.6 \pm 2.74$ \\
\hline $\begin{array}{c}\text { VLDL (mg/dl) } \\
\text { Mean } \pm \text { SEM }\end{array}$ & $10.5 \pm 0.7$ & $15.8 \pm 1.06$ & $12.8 \pm 0.8$ & $11.7 \pm 1.16$ & $11.2 \pm 0.9$ \\
\hline
\end{tabular}

NC- Normal control group

HC- Hperlipidemic control group

SD- Standard group

TG- Test group

SEM- Standard error mean 


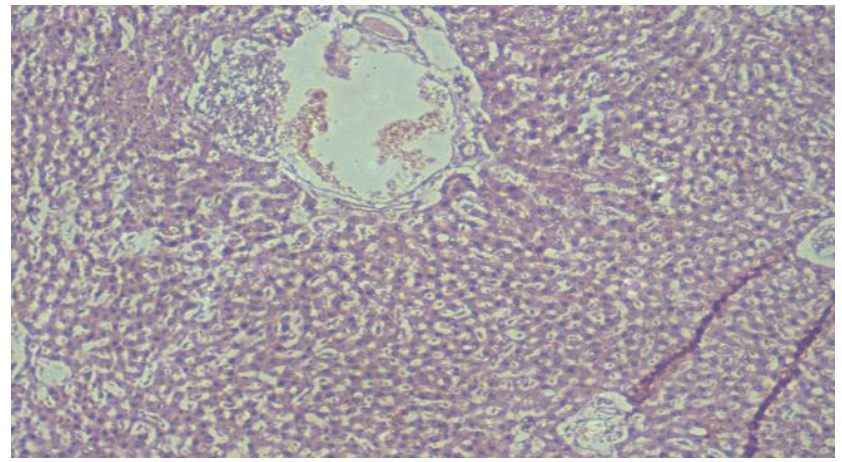

Fig-1

Photomicrograph of hyperlipdemic control rat liver tissue showing marked fatty degeneration of cells

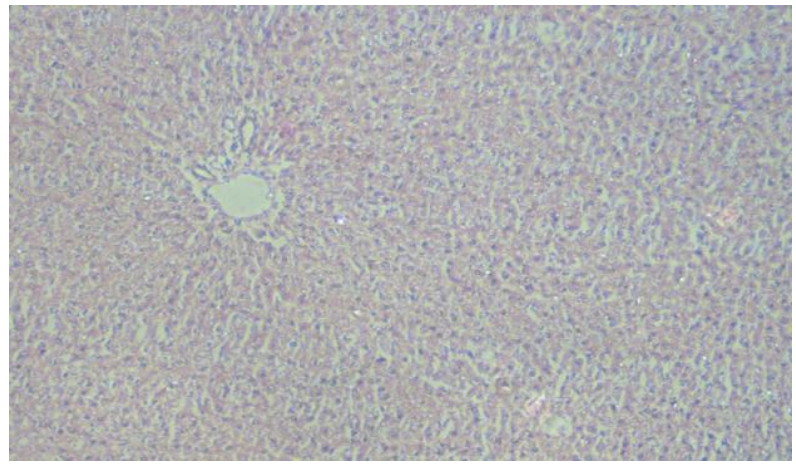

Fig-2

Photomicrograph of normal control rat liver tissue with no fatty degeneration

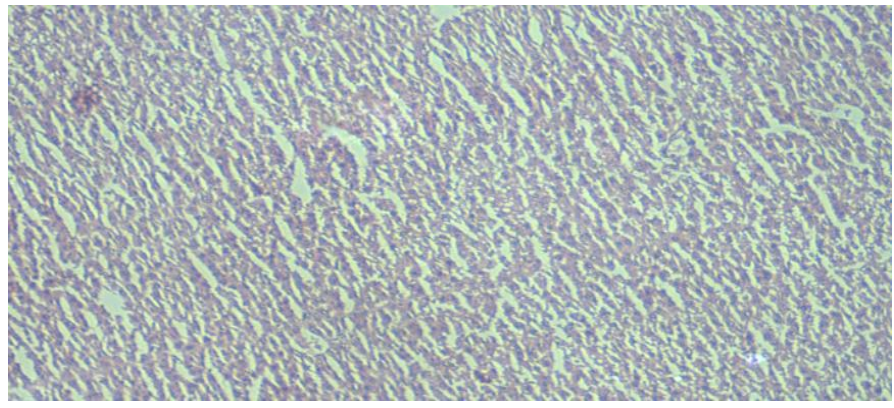

Fig-3

Photomicrograph of rat liver tissue treated with Lovastatin.

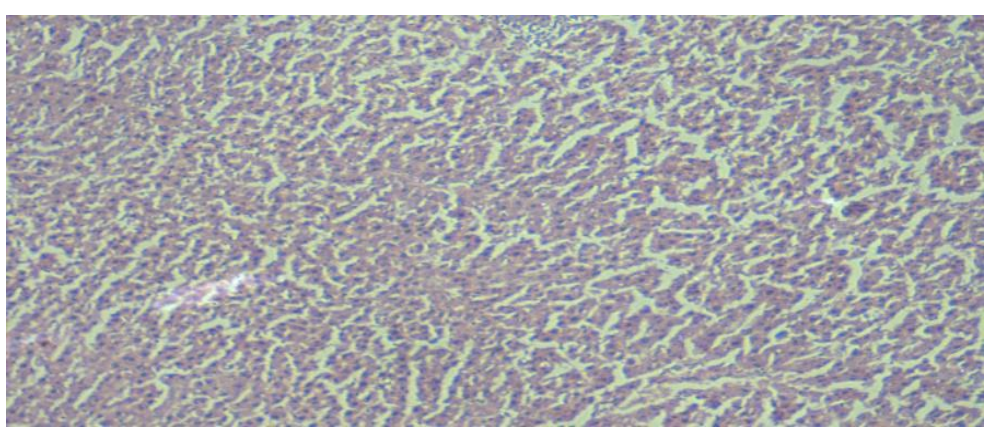

www.iosrjournals.org 


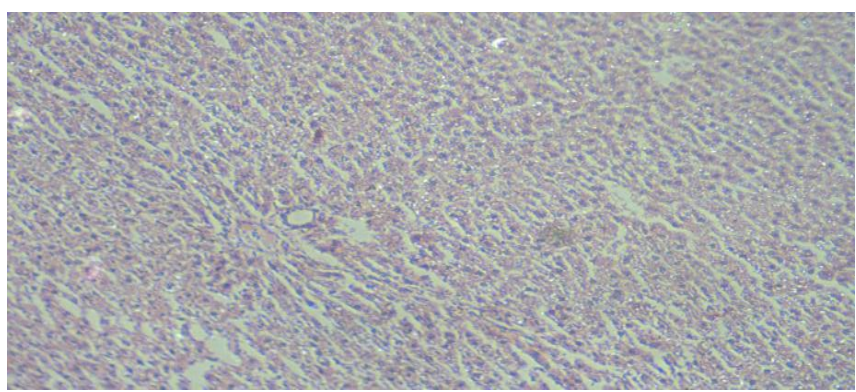

Fig-5

Photomicrograph of rat liver tissue treated with T.P $(800 \mathrm{mg} / \mathrm{kg} \mathrm{b.w})$.

\section{Discussion}

Hyperlipidemia became a mammoth and challenging health problem in the industrially developed and developing world. Atherosclerosis, referred to as a "silent killer", is one of the leading causes of death in the developed countries and is on the rise in developing countries like India. Based on this, it was postulated that reducing plasma lipid levels could reduce progression of coronary heart diseases (CHD) and improve clinical outcomes such as reduction in further occurrence of angina, myocardial infarction, stroke etc. In addition to hypertension, smoking, and diabetes mellitus, elevated serum cholesterol is considered an independent risk factor for the development of CHD and cerebrovascular diseases. Hyperlipidemia is the major risk factor in the initiation and progression of the atherosclerotic lesions.

Tephrosia purppurea (Linn) is a traditional plant used as hypolipidemic agent in tribal areas. It was found to be rich in phytochemical constituents which may have variety of pharmacological actions. In the literature survey, the phytochemical investigation made on this plant has reported the presence of phytochemicals like flavonoids, glycosides, and tannins etc. The data obtained in the present study indicates that ethanolic extract of Tephrosia purpurea (Linn) plant exhibited significant antihyperlipidemic activity against dexamethasone induced hyperlipidemia in a dose dependent manner.

There was a significant decrease in serum cholesterol levels in all the Tephrosia purpurea treated groups. However the fall in serum cholesterol was less than that of the group treated with Lovastatin. The percentage fall in serum cholesterol values of Tephrosia purpurea treated group increased depending on the dose given to the rats. However, the fall was not proportionate to the increase in the dose of Tephrosia purpurea. Lovastatin reduced triglyceride levels significantly, similar effect was observed in the animals treated with Tephrosia purpurea. There was slight increase in HDL levels in the Tephrosia purpurea treated group and the group given Lovastatin.

In the present study, flavonoids present in the ehanolic extract of plant (preliminary phytochemical screening) may be responsible for significant antihyperlipidemic activity against the selected experimental model. Thus the data obtained from phytochemical and pharmacological evaluations of extract of Tephrosia purpurea tend to suggest that ethanolic extract possess significant antihyperlipidemic activity in a dose dependent manner.

\section{Conclusion}

The ethanolic extract of plant of Tephrosia purpurea possess significant antihyperlipidemic activity in experimentally induced hyperlipidemic wistar rat. The antihyperlipidemic activity of ethanolic extract at dose of $400 \mathrm{mg} / \mathrm{kg}$ b.w. and $800 \mathrm{mg} / \mathrm{kg}$ b.w. was found to be significant as indicated by decrease in total cholesterol level of rats when compared to hyperlipidemic control. The present study demonstrated the possible therapeutic application of the plant of Tephrosia purpurea (Linn) in control of hyperlipidemia. However, further study on exact mechanism of action and fractionation of the extracts is a worthwhile effort to isolate the active principles responsible for the observed activity.

\section{Acknowledgement:}

This research was supported by Shadan College of Pharmacy. I am grateful to my supervisor Dr. R.K. Varma for his continuous support during the period of study. I would like to thank my current supervisors Dr. Lekhraj Rampal for his valuable advice on statistics part and Dr. Johnson Stanslas for his suggestions in manuscriprt preparation. 


\section{References}

[1]. Soni K, kumar SP, Saraf MN. Antioxidant activity of fraction of Tephrosia purpurea linn. Indian J Pharmaceutical Sciences 2006; 68 (4): 456-460.

[2]. Damre AS, Gokhale .AB, Phadke .AS, Kulkarni KR, Saraf MN. Studies on the immunomodulatory activity of flavonoidal fraction of Tephrosia purpurea. Fitoterpia 2003; 74 (3): 257-261.

[3]. Lodhi S, Pawar RS, Jain AP, Singhai AK. Wound healing potential of Tephrosia purpurea (Linn.) In Rats. Journal of Ethnopharmacology 2006; 108 (3): 204-210

[4]. Kavitha K, Manoharan S. Anticarcinogenic antilipidperoxidative effects of Tephrosia Purpurea (Linn.) pers. In 7, 12-di methylbenz(a) anthracene (DMBA) induced hamster buccal pounch carcinoma. Indian J Pharmacology 2006; 38 (3): $185-189$.

[5]. Jain A, Singhai AK, Dixit VK. A comparative study of ethanol extract of leaves of Tephrosia purpurea Pers and the flavonoid isolated for hepatoprotective activity. Indian J Pharmaceutical Sciences. 2006; 68 (3): 740-743.

[6]. Parmar VS, Rathore JS, Jain R, Deirdre A. Occurance of pongamol as the enol structure in Tephrosia purpurea. Phytochemistry 1989; 28 (2): 2339-2342

[7]. Rao VE, Raju RN. Two flavonoids from Tephrosia purpurea. Phytochemistry 1984; 23 (10): 2339-2342.

[8]. Sinha B, Natu AA, Nanavati DD. Phenylated flavonoids from Tephrosia purpurea seeds. Phytochemistry 1982; 21(6): 1468-1470.

[9]. Gupta DK, Krishnamurthy M, Parthasarathi L. Purpurin, a new flavones from Tephrosia purpurea seeds. Phytochemistry $1980 ; 19$ (6): 1264

[10]. Rao VE, Raju RN. Occurance of (-)-isolonchocarpine in the roots of Tephrosia Purpurea. Phytochemistry $1979 ; 18$ (9): $1581-82$.

[11]. Ahmad VU, Ali Z, Hussaini SR, Iqbal M, Zahid M, Abbas M, Saba N. Flavonoids of Tephrosia purpurea. Fitoterpia 1999; 70: 443445 .

[12]. Das N and Mukherjee M. Cultivation of pleurotus ostreatus on weed plants. Bioresource Technology 11 December 2006.

[13]. Saleem M, Ahmed S, Alam A, Sultana S. Tephrosiapurpurea alleviates phorbol ester- induced tumour promotion response in murine skin. Phramcolgical Research 2001; 43 (2): 135-144.

[14]. Rafaie FM, Esmat AY, Gawad SAM, Ibrahim AM and Mohamed MM. The antihyperlipidemic activities of 4 (3H) quinazoline and two halogenated derivatives in rats. 2005; volume 4.

[15]. Chattopadhyay RR, Bandyopadhyay M. Effect of Azadirachta indica leaf extract on serum lipid profile changes in normal and steptozotocin induced diabetic rats. African J of Biomedical Research 2005; 8 (2): 101-104.

[16]. Dubey AK, Devi A, Kutty G and Shankar. RP. Hypolipidemic activity of Ginkgo biloba. Extract, EGb 761 in Hypercholesterolemic Wistar Rats. Iranian J of Pharmacology \& Therapeutics 2005

[17]. Veraraghavan P. Expert consultant, CPCSEA, OECD guideline no. 420.

[18]. Allain C, Chan SG., Richmond WP., Enzymatic determination of total serum cholesterol. Clin Chem 1974; 20: 470-471.

[19]. Varley H, Gowenlock AH, Bell M, Practical Clinical Biochemistry. $5^{\text {th }}$ Edition, Vol (1): 659. 